\title{
A Pilot Study of Younger Sibling Adaptation: Contributions of Individual Variables, Daily Stress, Interparental Conflict and Older Sibling's Variables
}

\author{
Laura Merino ${ }^{1}$, Ana Martínez-Pampliega ${ }^{1}$, David Herrero-Fernández ${ }^{2}$ \\ [1] Social and Developmental Psychology Department, Psychology and Education Faculty, University of Deusto, Bilbao, Spain. [2] Health Sciences Faculty, \\ European University of the Atlantic, Santander, Spain.
}

Europe's Journal of Psychology, 2021, Vol. 17(2), 1-12, https://doi.org/10.5964/ejop.2139

Received: 2019-08-30 • Accepted: 2020-06-26 • Published (VoR): 2021-05-31

Handling Editor: Michelle E. Roley-Roberts, The Ohio State University Wexner Medical Center, Columbus, OH, USA

Corresponding Author: Laura Merino, Departamento de Psicología Social y del Desarrollo, Facultad de Psicología y Educación, Universidad de Deusto. Avda. de las Universidades, 2448007 Bilbao, Spain. Tel.: +34 2756944139000 , E-mail: laura.merino@deusto.es

\begin{abstract}
Older siblings are powerful socialization agents, playing a significant role in the sociocognitive, social, and emotional development of their younger siblings. However, there are few clues about the variables that explain younger sibling's adaptation. The objective of this pilot study was to identify the determinants of younger siblings' adaptation and to analyze the role played by personal, sibling, family and older siblings' variables using 50 dyads of siblings aged between 7 and 18 years. The variables considered were the sibling relationships and the maladaptation of older siblings, and individual (sex, number of siblings, extroversion, and agreeableness) and contextual variables (interparental conflict, daily stress) were controlled. Hierarchical multiple regressions provided evidence in favor of the model that analyzed the younger siblings' maladaptation to school, showing positive associations both with the older siblings' level of school maladaptation and with sibling conflict. In addition, the study highlighted the relevance of the trait of agreeableness and of family stress in the adaptation of younger siblings.
\end{abstract}

\section{Keywords}

sibling relations, interparental conflict, temperament, sibling dyads, child siblings

Siblings spend a lot of time together every day and this shared time has become an important scenario of socialization (Kumar, Thomas, \& Deb, 2015; Updegraff, McHale, Whiteman, Thayer, \& Delgado, 2005) in different cultures (Buist et al., 2014). In the 1980s, numerous works began to describe the influence of sibling relations on the social and emotional development of children and adolescents (Menesini, Camodeca, \& Nocentini, 2010). Since then, the literature has highlighted that relationships among siblings are relevant for the comprehension of children's sociocognitive (Dunn, Brown, Slomkowski, Tesla, \& Youngblade, 1991), social (Kramer \& Bank, 2005; McElwain \& Volling, 2005) and emotional development (Brown \& Dunn, 1996), and therefore, siblings can be considered powerful socialization agents. This is reflected when the children highlight their sense of collectivity and of feeling part of a group, as well as protection and emotional security as the greatest contributions of their siblings in their lives (Edwards, Mauthner, \& Hadfield, 2005).

Therefore, developmental psychologists have analyzed the contributions of sibling relations to the process of socialization of children and adolescents (Brody, 1998; Dunn, Slomkowski, \& Beardsall, 1994; Kramer \& Conger, 2009; Kumar et al., 2015). In addition, these sibling relations have an important impact on children's psychological well-being (McHale, Updegraff, \& Whiteman, 2012; Ponappa, Bartle-Haring, Holowacz, \& Ferriby, 2017) and increasingly more results appear that underscore this (Conger \& Kramer, 2010; Kennedy \& Kramer, 2008). 
Concerning ways for the older siblings' socialization of the younger one, an extensive literature has shown that social learning and modeling are key processes through which older siblings influence the behavior and adaptation of their younger siblings (Bandura, 2001; Whiteman, Becerra Bernard, \& McHale, 2010). One of the most supported perspectives to explain the mechanisms associated with some behavioral problems and the relationship between siblings is Bandura's (1973) social learning theory, applied specifically to this field through the work carried out by Patterson (1984), and Dunn and Munn (1986).

Following this line, various studies have examined the role of big brother/sister as a significant model in the socialization of the other siblings in different areas, both positive and negative: alcohol and drug use (Fagan \& Najman, 2005; Slomkowski, Rende, Novak, Lloyd-Richardson, \& Niaura, 2005; Trim, Leuthe, \& Chassin, 2006; Tsamparli \& Frrokaj, 2016); gambling (Canale et al., 2017); sexual behavior and teen pregnancies (East \& Jacobson, 2001; McHale, Bissell, \& Kim, 2009; Patterson, 1984; Rodgers, Rowe, \& Harris, 1992; Slomkowski et al., 2005; Wheeler et al., 2016); risky health behavior (D’Amico \& Fromme, 1997); externalizing and internalizing behaviors (Branje, Van Lieshout, Van Aken, \& Haselager, 2004); criminal offences (Slomkowski, Rende, Conger, Simons, \& Conger, 2001); attitudes and activities according to gender role (Crouter, Whiteman, McHale, \& Osgood, 2007; McHale, Updegraff, Helms-Erikson, \& Crouter, 2001); intimacy and control in friendship relations (Updegraff, McHale, \& Crouter, 2002); academic and leisure interests (Jensen \& McHale, 2015; Whiteman, McHale, \& Crouter, 2007), and development of empathy (Tucker, Updegraff, McHale, \& Crouter, 1999) and social skills (Stormshak et al., 1996).

Specifically, older siblings can be a significant authority to learn how to succeed in the area of friends, particularly in environments outside the home, such as school or neighborhood (Zukow-Goldring, 2002). Although there are few works that analyze the function of siblings in academic performance, there is evidence that highlights the role of the siblings as possible significant models for academic success (Bouchey, Shoulberg, Jodl, \& Eccles, 2010; Jensen, Pond, \& Padilla-Walker, 2015).

\section{Transfer to Other Socialization Contexts}

Finally, some researchers postulate that sibling relations are a training stage for social skills where children and adolescents acquire interpersonal strategies that they also transfer to adaptive behaviors in other contexts, such as their friendship relations (Buhrmester, 1992; Menesini et al., 2010). Regardless of the quality of the sibling relations, the stage shared by the siblings is a privileged social context where they receive and give affection, establish interactions of play, and put into practice negotiation and conflict-resolution skills (Dunn et al., 1994), as well as prosocial behaviors (Pike \& Oliver, 2017) that will serve them in their peer relations outside of the family. Some studies reaffirm the idea that there is a strong association between sibling relations and friendship relations in young adults (MacKinnon-Lewis, Starnes, Volling, \& Johnson, 1997; Stormshak et al., 1996).

\section{Other Relevant Variables in Adaptation: Family Socialization Context and Individual Variables}

Regarding family variables that affect individual adaptation, numerous investigations have revealed a significant relationship between interparental conflict and child adaptation difficulties (Buchanan \& Heiges, 2001; Davies, Martin, \& Cicchetti, 2012; Morgado Camacho \& González Rodríguez, 2001; Dillman Taylor, Purswell, Lindo, Jayne, \& Fernando, 2011), highlighting internalizing (Hornor, 2005) and externalizing symptoms (Formoso, Gonzales, \& Aiken, 2000) and problems with children's social relations (e.g., sibling and peer relationships; Martínez-Pampliega et al., 2015).

Everyday family stressors can also lead to children's poorer adaptation (Crnic \& Greenberg, 1990). For example, it has been shown that the daily problems derived from child-raising, difficulties to combine work and family life, and marital conflicts have a negative impact on families and children (Crnic, Gaze, \& Hoffman, 2005; Crnic \& Greenberg, 1990; Crouter, Bumpus, Head, \& McHale, 2001; Lee, Vernon-Feagans, Vazquez, \& Kolak, 2003). In this sense, there is much evidence of the influence of family stressors on children's concern about their family relationships and, therefore, their involvement in them (cf. for a review, see Cummings, Davies, \& Simpson, 1994). Children whose family must deal with stressors that are maintained over time show greater sensitization to stress, which increases their reaction, concern, and efforts to exert some control and power in the situation of family distress (Nixon \& Cummings, 1999). 
Regarding individual variables that affect individual adaptation, many personality traits predict the individual's social competences. For instance, more extroverted and agreeable children are socially more competent over time, whereas children with high levels of negative emotionality and low levels of frustration have more social problems such as aggressive behaviors, anger, anxiety, and avoidance (Asendorpf \& Van Aken, 2003).

\section{Aim of the Study}

Therefore, the objective of this pilot study is to identify the determinants of younger siblings' adaptation and to analyze the role played by personal, sibling, family and older sibling's variables. For this purpose, we intended to differentiate the contributions of sex, personality, age, number of siblings, experienced daily stress, perceived interparental conflict, sibling relationships, and the older sibling's individual variables (personal, social, school, and family maladaptation) to explain the younger sibling's adaptation.

\section{Method}

\section{Participants}

The sample was made up of 50 pairs of siblings relatively close in age within dyads, with age ranging between 7 and 18 years across dyads, mean age 11.9 years $(S D=2.81)$. The mean age of the older siblings was 13.3 years $(S D=2.30)$ and the mean age of the younger siblings was 10.5 years $(S D=2.30)$. On the one hand, 28 older siblings were boy, whereas other 22 older siblings were girls. On the other hand, 22 younger siblings were boys, whereas 28 younger siblings were girls. The families of these pairs of siblings had an average of 2.3 children $(S D=0.58)$. The sample had the same number of boys and girls, 50 , respectively.

We used a sample that was restricted to the population of students of the historical territory of Bizkaia (Autonomous Community of the Basque Country). The sample of participants was made up of pairs of siblings from different public and private schools. The inclusion criteria for participation in this study were: being a student of between 3rd grade of Primary School and 2nd grade of High School of the Spanish educational system; the participants should be biological or adoptive siblings (despite the fact that there were no adoptive siblings). The exclusion criterion was having a lot of difficulty to understand the questionnaires. The inclusion and exclusion criteria were formulated a priori.

Regarding the parents' marital status, most were married in first nuptials (67\%), followed by divorced couples (27\%), and the remaining couples were either married in second nuptials (4\%) or living with a partner $(2 \%)$. About $60 \%$ of the fathers and mothers were middle or highly qualified professionals (fathers $=59.6 \%$, mothers $=58 \%$ ), whereas the greatest differences between fathers and mothers were found in the number of unskilled workers (fathers $=14.9 \%$, mothers $=36 \%$ ), executives (fathers $=8.5 \%$, mothers $=0 \%$ ), workers in small businesses (fathers $=12.8 \%$, mothers $=6 \%$ ), and unemployed workers (fathers $=4.3 \%$, mothers $=2 \%$ ). Nevertheless, there was no significant differences on the working situation between fathers and mothers $\left(\chi^{2}=20.418, p=.432\right)$.

\section{Procedure}

To implement the assessment protocol, we contacted the school principals and counselors of various schools of Bizkaia, according to the researcher's convenience, but attempting to achieve representativeness in terms of source of financing (public and concerted schools) and location (different neighborhoods and cities). We attended to all the families from all these schools that were interested in participating in the study and that met the inclusion criteria.

When contacting the schools, we explained the general goal of the study, emphasizing that the school's collaboration only consisted of passing on the information about the study to the families. The participation of the families in the study required that two of their children complete questionnaires. The parents who were interested in the participation of two of their children subsequently contacted the researcher via email or phone. In this first contact with the families, we explained the main purpose of the study, ensuring confidentiality and anonymity of the data, and that we would give 5 euros to each sibling for their cooperation. Each family chose the most convenient date and time for them to participate in the study. They could participate in a classroom of their children's school or on the premises of 
DeustoPsych (Psychological laboratory of the University of Deusto). The parents of the participants signed an informed consent. Both siblings answered all the questionnaires in a room where a research assistant was available to solve any doubts and support the youngest participants with the questionnaire fulfillment.

\section{Instruments}

\section{Sibling Relationship}

Sibling Relationships Questionnaire (SRQ) - This child self-report, SRQ (Furman \& Buhrmester, 1985), assesses the quality of sibling relationship through 48 items (e.g., "How often do you and your sibling go places or do things together?"), of which the first 42 items are rated on a 5-point Likert type scale ranging from 1 (Hardly at all) to 5 (Very much). The exception are 6 items about maternal and paternal partiality, which assess favoritism, attention, and differential treatment of siblings by the mother and the father on a 5-point Likert scale ranging from -2 (almost always favors/pays attention to/treats my sib better than me) to 2 (almost always favors/pays attention to/treats me better). The SRQ has 16 scales (Prosocial, Similarity, Intimacy, Companionship, Admiration by Sibling, Admiration of Sibling, Affection, Nurturance by Sibling, Nurturance of Sibling, Dominance by Sibling, Dominance of Sibling, Antagonism, Competition, Quarreling, Maternal and Paternal Partiality) whose score is calculated by summing the mean score of the 3 items of each scale. In turn, the scales are grouped into four main dimensions of sibling relationships (Warmth/Closeness, Sibling Power/Status, Conflict and Maternal/Paternal Partiality) that are the ones used in this study. Each main dimension is calculated by adding its scales, except for the dimension of Sibling Power/Status which, by recommendation of the original authors of the SRQ (Furman \& Buhrmester, 1985), is calculated by subtracting passive from active scores: (Nurturance by Sibling + Dominance by Sibling) - (Nurturance of Sibling + Dominance of Sibling). There were no validated questionnaires in Spanish to assess sibling relationships, so the English version of SRQ was translated, adapted and validated to Spanish in another study (author, unpublished manuscript), and it replicates the original structure. Validity information for the Sibling Relationships Questionnaire can be obtained from the main author of this manuscript. In this study, the reliabilities of the four main factors were: Warmth/Closeness $\alpha=.88$, Sibling Power/Status $\alpha=.83$, Conflict $\alpha$ $=.76$, and Partiality $\alpha=.56$.

\section{Family Variables}

Children's Perception of Interparental Conflict Scale (CPIC-Y) - We used the Spanish version adapted from the original scale (McDonald \& Grych, 2006), which replicates the structure of the three main scales although the items are grouped in different subscales (author, unpublished manuscript). This self-report for children and adolescents contains 22 dichotomous items $(1=$ Yes, $0=$ No) grouped into three scales: (1) Conflict Properties: this includes 11 items distributed in three subscales, with 6 items about children's perception of Negative Interparental Conflict, 3 items about their perception of Constructive Interparental Conflict and 2 items about their perception of Aggression in Interparental Conflict (e.g., "I've seen or heard my father and my mother arguing"); (2) Threat Scale: the second scale has 6 items referring to the children's feelings of threat and fear in the face of interparental conflict (e.g., "I get scared when my father and my mother argue"); (3) and Self-Blame: the third scale includes 4 items related to the children's feelings of self-blame for interparental conflict (e.g., "When my father and my mother argue, it is usually my fault”). The reliability indices (McDonald's $\omega$, as the items were dichotomous) in this study were: Conflict Properties $\omega=.82$, Threat $\omega=.81$, Self-Blame $\omega=.48$.

Inventario Infantil de Estresores Cotidianos [Child Inventory of Everyday Stressors] (IIEC) - This 41-item inventory (School and Peer and Family dimensions), which presents everyday stressors selected by experts as representative of the construct of daily stress (Trianes Torres et al., 2009), is rated by the children $(1=$ Yes, $0=N o)$. The Cronbach alpha internal consistency of the test is .70 and the test-retest reliability reaches a score of .78 (Trianes Torres et al., 2009). Only the items relating to the area of School and Peers (School and social stress: 12 items) and Family (Family stress: 17 items) were used in this study. The reliability index (McDonald's omega, as the items were dichotomous) in this study for the dimension of School and Social stress was $\omega=.49$ and for Family stress, it was $\omega=.61$. 


\section{Personality Traits}

Big Five Questionnaire-Children and Adolescents (Dimensions of Extroversion and Agreeableness) - For this study, we only evaluated two dimensions that are most closely linked to interpersonal relationships: Extroversion and Agreeableness (Barbaranelli, Caprara, Rabasca, \& Pastorelli, 2003). These dimensions contain 13 and 12 items, respectively, which describe the frequency of occurrence of certain extroversion and agreeableness traits. Items are rated on a 5-point Likert scale ranging from 1 (hardly ever) to 5 (almost always). This instrument has solid international psychometric support (Barbaranelli, Caprara, \& Rabasca, 2006), where Extraversion reached a Cronbach alpha of .71 and Agreeableness reached a Cronbach alpha of .80. However, we used the Spanish version adapted by Ortiz, Tello, and del Barrio Gándara (2005) and, in this study, Cronbach's alpha was .66 for Extroversion and .84 for Agreeableness.

\section{Child Adaptation}

Test Autoevaluativo Multifactorial de Adaptación Infantil [Multifactorial Child Adaptation Self-Assessment Test] (TAMAI) - This questionnaire (Hernández, 1983) evaluates children's general, personal, school, and social maladaptation, and dissatisfaction with family and siblings through 175 dichotomous items $(1=$ Yes, $0=$ No $)$ answered directly by the children. Children's maladaptation is described as the appearance of difficulties and problems in the contexts where children participate (persona, social, school and family). In this study, we used the scales of general, personal, school, and social maladaptation and family dissatisfaction: (1) The Personal Maladaptation scale has 39 items and encompasses both self-maladaptation and maladaptation to manage daily issues or a personal difficulty to accept reality; it had a McDonald's omega reliability of .84; (2) The School Maladaptation scale includes 31 items assessing poor learning performance and disruptive behavior in the classroom; it obtained a McDonald's omega of .81; (3) The Social Maladaptation scale describes the degree of difficulty in social relationships through 35 items; it had a McDonald's omega of .78. These three scales are grouped into a single dimension called General Maladaptation; (4) The Family Dissatisfaction scale includes 5 items that indicate the degree of dissatisfaction with the climate of the home and the interparental relationship; its McDonald's omega reliability was .60. In this study, the internal reliabilities of the dimensions were adequate (General Maladaptation $\omega=.91$, Personal Maladaptation $\omega=.84$, School Maladaptation $\omega$ $=.81$, Social Maladaptation $\omega=.78$, Family Dissatisfaction $\omega=.60)$.

\section{Analysis Strategy}

First, descriptive statistics (mean, standard deviation, and range) of all the variables were calculated. After verifying the normality of variables, we calculated the bivariate correlation matrix (Pearson's $r$ ) among the main variables of the study. Only young siblings' data were included to calculate the descriptive statistics and the correlations. Lastly, we conducted a hierarchical multiple regression to analyze the variables that explain a greater percentage of the variance of the younger siblings' adaptive behavior. Demographics (sex, age, number of siblings in the family) and temperament variables (extraversion and agreeableness) were introduced in the first block; in the second step, we included family variables (threat, self-blame, and properties of interparental conflict; school and social stress and family stress); the third step included sibling relations (warmth, conflict, power, and partiality); and the last step included the variable of the older sibling's maladjustment corresponding to the dependent variable in each model (e.g., if the dependent variable is the younger sibling's school maladjustment, in this fourth step, we included the variable of the older sibling's school maladjustment). Statistical power was calculated for each one of the five regression models with $G^{*}$ Power (Version 3.1.9.4) software (Faul, Erdfelder, Lang, \& Buchner, 2007).

\section{Results}

\section{Descriptive Analysis}

Table 1 provides means, standard deviations, and correlations for key study variables based on the data of younger siblings. Regarding the individual variables, significant associations emerged, especially between the trait of agreeableness and the level of individual maladjustment in the total score, and in social, family, and school maladaptation, with 
significant, negative and small or moderate correlations. With regard to family variables, the data showed that both the properties of interparental conflict and the feeling of self-blame for it and daily social and school stress were significantly and positively associated with different levels of maladaptation. Finally, regarding the sibling variables, sibling warmth was significantly and negatively associated with all levels of maladaptation, except for the level of personal maladaptation. However, sibling conflict was significantly and positively associated with the younger sibling's total and school maladaptation scores.

Table 1

Descriptive Statistics and Correlations Between Variables of the Data From Younger Siblings

\begin{tabular}{|c|c|c|c|c|c|c|c|c|c|c|c|c|c|c|c|c|c|c|c|c|}
\hline Variable & $M$ & $S D$ & Range & 2 & 3 & 4 & 5 & 6 & 7 & 8 & 9 & 10 & 11 & 12 & 13 & 14 & 15 & 16 & 17 & 18 \\
\hline 1. Age & 10.40 & 2.33 & $7-16$ & .16 & .16 & -.08 & $-.55^{\star *}$ & -.08 & .13 & -.07 & .10 & .22 & -.13 & $.35^{*}$ & .05 & -.03 & .06 & -.18 & -.17 & .08 \\
\hline 2. Number of siblings & 2.32 & 0.59 & $2-4$ & & -.17 & -.12 & -.03 & -.06 & .20 & .22 & $.53^{\star \star}$ & -.02 & -.12 & -.16 & $.32^{*}$ & .04 & .22 & -.26 & -.04 & .22 \\
\hline 3. Extroversion & 44.64 & 6.07 & $27-57$ & & & $.63^{\text {** }}$ & .04 & .20 & .02 & -.09 & -.05 & $.61^{* *}$ & .08 & .26 & .18 & -.23 & -.26 & .04 & -.13 & $-.29^{k}$ \\
\hline 4. Agreeableness & 52.33 & 7.97 & $32-68$ & & & & .07 & -.01 & -.20 & -.21 & .05 & $.54^{* *}$ & .23 & -.14 & .15 & $-.40^{\star *}$ & $-.38^{* *}$ & -.08 & -.25 & $-.43^{\text {** }}$ \\
\hline 5. Threat & 3.48 & 2.09 & $0-6$ & & & & & .12 & .16 & -.05 & .15 & -.23 & .18 & -.13 & .23 & .17 & .06 & .26 & .22 & .11 \\
\hline 6. Self-blame & 0.48 & 0.91 & $0-4$ & & & & & & .07 & .07 & -.07 & -.02 & .18 & .11 & .20 & .27 & .10 & $.48^{* *}$ & .23 & .05 \\
\hline 7. Conflict properties & 2.86 & 2.53 & $0-11$ & & & & & & & $.32^{*}$ & .19 & -.29 & .22 & .11 & .21 & $.34^{*}$ & .23 & .20 & $.55^{* *}$ & $.36^{*}$ \\
\hline 8. School and social stress & 1.58 & 1.30 & $0-5$ & & & & & & & & .05 & $-.34^{*}$ & .07 & .03 & -.03 & $.31^{*}$ & $.44^{* *}$ & .05 & .08 & .28 \\
\hline 9. Family stress & 1.31 & 1.42 & $0-6$ & & & & & & & & & -.07 & -.16 & -.08 & .10 & -.05 & .08 & -.12 & .11 & -.02 \\
\hline 10. Sibling warmth & 76.72 & 11.38 & $52-105$ & & & & & & & & & & -.19 & .07 & .05 & $-.41^{* *}$ & $-.42^{* *}$ & -.20 & $-.33^{*}$ & $-.34^{*}$ \\
\hline 11. Sibling conflict & 26.08 & 6.71 & $10-40$ & & & & & & & & & & & .02 & .16 & $.35^{*}$ & .11 & $.37^{\star}$ & .27 & $.32^{*}$ \\
\hline 12. Sibling power & -5.92 & 5.57 & $-16-5$ & & & & & & & & & & & & .09 & .09 & .01 & .11 & -.04 & .07 \\
\hline 13. Parental partiality & 0.46 & 2.31 & $-8-8$ & & & & & & & & & & & & & .14 & .16 & .09 & -.15 & .16 \\
\hline $\begin{array}{l}\text { 14. General maladaptation } \\
\text { of younger sibling }\end{array}$ & 27.02 & 12.02 & $5-60$ & & & & & & & & & & & & & & $.83^{* *}$ & $.80^{* *}$ & $.45^{\text {** }}$ & $.79^{* *}$ \\
\hline $\begin{array}{l}\text { 15. Social maladaptation } \\
\text { of younger sibling }\end{array}$ & 7.96 & 4.38 & $0-23$ & & & & & & & & & & & & & & & $.51^{* *}$ & .28 & $.55^{\star \star}$ \\
\hline $\begin{array}{l}\text { 16. Personal } \\
\text { maladaptation of younger } \\
\text { sibling }\end{array}$ & 9.39 & 5.50 & $0-22$ & & & & & & & & & & & & & & & & $.41^{\star \star}$ & $.36^{*}$ \\
\hline $\begin{array}{l}\text { 17. Family dissatisfaction } \\
\text { of younger sibling }\end{array}$ & 0.56 & 0.93 & $0-3$ & & & & & & & & & & & & & & & & & $.38^{* *}$ \\
\hline $\begin{array}{l}\text { 18. School maladaptation } \\
\text { of younger sibling }\end{array}$ & 9.18 & 5.03 & $1-19$ & & & & & & & & & & & & & & & & & - \\
\hline
\end{tabular}

\section{Associations Between Maladaptation and Dissatisfaction of Younger and Older Siblings}

Table 2 shows the correlations between general, social, personal and school maladaptation and family dissatisfaction of younger and older siblings. Only two correlations are significant: family dissatisfaction of younger sibling has a significant and positive association with the family dissatisfaction of older sibling; and younger sibling's school maladaptation has a significant and positive association with the older sibling's school maladaptation.

Table 2

Correlations Between Maladaptation Variables of Younger and Older Siblings

\begin{tabular}{lccccc}
\hline & $\begin{array}{c}\text { General } \\
\text { maladaptation of } \\
\text { older sibling }\end{array}$ & $\begin{array}{c}\text { Social } \\
\text { maladaptation of } \\
\text { older sibling }\end{array}$ & $\begin{array}{c}\text { Personal } \\
\text { maladaptation of } \\
\text { older sibling }\end{array}$ & $\begin{array}{c}\text { Family } \\
\text { dissatisfaction of } \\
\text { older sibling }\end{array}$ & $\begin{array}{c}\text { School } \\
\text { maladaptation of } \\
\text { older sibling }\end{array}$ \\
\hline $\begin{array}{l}\text { General maladaptation of } \\
\text { younger sibling }\end{array}$ & .19 & .19 & .15 & .11 & .18 \\
$\begin{array}{l}\text { Social maladaptation of } \\
\text { younger sibling }\end{array}$ & .24 & .26 & .26 & .21 & .10
\end{tabular}




\begin{tabular}{|c|c|c|c|c|c|}
\hline Variable & $\begin{array}{c}\text { General } \\
\text { maladaptation of } \\
\text { older sibling }\end{array}$ & $\begin{array}{c}\text { Social } \\
\text { maladaptation of } \\
\text { older sibling }\end{array}$ & $\begin{array}{c}\text { Personal } \\
\text { maladaptation of } \\
\text { older sibling }\end{array}$ & $\begin{array}{c}\text { Family } \\
\text { dissatisfaction of } \\
\text { older sibling }\end{array}$ & $\begin{array}{c}\text { School } \\
\text { maladaptation of } \\
\text { older sibling }\end{array}$ \\
\hline $\begin{array}{l}\text { Personal maladaptation of } \\
\text { younger sibling }\end{array}$ & -.01 & .04 & .11 & .19 & -.08 \\
\hline $\begin{array}{l}\text { Family dissatisfaction of } \\
\text { younger sibling }\end{array}$ & .07 & -.01 & -.08 & $.37^{*}$ & .23 \\
\hline $\begin{array}{l}\text { School maladaptation of } \\
\text { younger sibling }\end{array}$ & .24 & .18 & .04 & .12 & $.37^{*}$ \\
\hline
\end{tabular}

\section{Predicting Young Siblings’ Adaptation}

Table 3 reports results from five hierarchical multiple regression models that predicted younger siblings' maladaptation from individual, family, and sibling variables. As it can be observed, all of the models attained high statistical power $(1-\beta)$, with values ranging from $87.4 \%$ to $99.4 \%$. Only the model that explains the younger sibling's school maladjustment was significant, accounting for $68 \%$ of the variance. Specifically, this model had four variables that yielded a significant association with the younger sibling's school maladjustment: sex was negatively associated, and family stress, sibling conflict, and the older sibling's level of school maladjustment were positively associated. The other models were not significant to explain the younger sibling's maladaptation but two variables-younger sibling's sex (negative correlation) and family stress (positive correlations)-were significantly associated with the younger sibling's maladaptation. Lastly, the younger sibling's family maladjustment was also significantly and negatively associated with the number of siblings in the family and with sibling partiality.

Table 3

Hierarchical Multiple Regression Analysis to Predict Younger Sibling Adaptation ( $N=50)$

\begin{tabular}{|c|c|c|c|c|c|c|c|c|c|c|c|c|c|c|c|}
\hline \multirow[b]{2}{*}{ Variable } & \multicolumn{3}{|c|}{$\begin{array}{c}\text { General } \\
\text { maladaptation of } \\
\text { younger sibling } \\
(1-\beta=99.4 \%)\end{array}$} & \multicolumn{3}{|c|}{$\begin{array}{c}\text { Social maladaptation } \\
\text { of younger sibling } \\
(1-\beta=87.4 \%) \\
\end{array}$} & \multicolumn{3}{|c|}{$\begin{array}{c}\text { Personal } \\
\text { maladaptation of } \\
\text { younger sibling } \\
(1-\beta=98.8 \%)\end{array}$} & \multicolumn{3}{|c|}{$\begin{array}{c}\text { Family dissatisfaction } \\
\text { of younger sibling } \\
(1-\beta=99.4 \%)\end{array}$} & \multicolumn{3}{|c|}{$\begin{array}{c}\text { School maladaptation } \\
\text { of younger sibling } \\
(1-\beta=98.5 \%)\end{array}$} \\
\hline & $\mathbf{B}^{\mathbf{a}}$ & $S E \mathbf{B}^{\mathbf{a}}$ & $\beta^{\mathbf{a}}$ & $\mathbf{B}^{\mathbf{b}}$ & $S E \mathbf{B}^{\mathbf{b}}$ & $\beta^{\mathbf{b}}$ & $\mathbf{B}^{\mathbf{c}}$ & $S E \mathbf{B}^{\mathrm{c}}$ & $\beta^{\mathbf{c}}$ & $\mathbf{B}^{\mathrm{d}}$ & $S E \mathbf{B}^{\mathrm{d}}$ & $\beta^{d}$ & $\mathbf{B}^{\mathrm{e}}$ & $S E B^{\mathrm{e}}$ & $\boldsymbol{\beta}^{\mathbf{e}}$ \\
\hline Age & 1.47 & 1.43 & .28 & 0.01 & 0.50 & .01 & 0.38 & 0.66 & .16 & -0.09 & 0.07 & -.22 & 0.81 & 0.46 & $.38^{\dagger}$ \\
\hline Gender $(1=$ boy, 2 = girl $)$ & -8.88 & 4.38 & $-.37^{\dagger}$ & -1.18 & 1.64 & -.13 & -1.43 & 2.01 & -.13 & -0.48 & 0.25 & $-.27^{\dagger}$ & -4.58 & 1.61 & $-.45^{*}$ \\
\hline Number of siblings & 0.03 & 4.06 & .01 & 1.36 & 1.61 & .15 & -2.833 & 2.06 & -.27 & -0.71 & 0.29 & $-.38^{*}$ & 1.49 & 1.56 & .15 \\
\hline Extroversion & -0.10 & 0.59 & -.06 & -0.05 & 0.23 & -.07 & 0.10 & 0.27 & .13 & -0.02 & 0.04 & -.12 & -0.26 & 0.23 & -.34 \\
\hline Agreeableness & -0.52 & 0.43 & -.37 & -0.15 & 0.17 & -.28 & -0.14 & 0.21 & -.22 & -0.03 & 0.03 & -.28 & -0.21 & 0.16 & -.35 \\
\hline Threat & 0.80 & 1.58 & .13 & -0.45 & 0.57 & -.21 & 0.58 & 0.68 & .21 & -0.01 & 0.09 & -.03 & 0.54 & 0.52 & .22 \\
\hline Self-blame & 0.34 & 2.98 & .03 & -0.68 & 0.83 & -.15 & 1.98 & 1.24 & .35 & 0.16 & 0.13 & .18 & -0.25 & 0.82 & -.05 \\
\hline Conflict properties & 0.40 & 1.81 & .06 & 0.28 & 0.56 & .11 & -0.61 & 0.80 & -.20 & 0.10 & 0.11 & .19 & 0.40 & 0.55 & .14 \\
\hline School and social stress & 0.75 & 1.85 & .09 & 0.39 & 0.69 & .11 & 0.07 & 0.88 & .02 & 0.01 & 0.11 & .01 & 0.30 & 0.62 & .08 \\
\hline Family stress & 3.43 & 1.61 & $.43^{*}$ & 1.33 & 0.63 & $.42^{*}$ & 1.60 & 0.76 & $.44^{*}$ & 0.27 & 0.10 & $.42^{*}$ & 0.86 & 0.60 & .25 \\
\hline Sibling warmth & -0.02 & 0.27 & -.02 & -0.09 & 0.11 & -.24 & -0.05 & 0.12 & -.12 & 0.02 & 0.02 & .24 & 0.14 & 0.10 & .32 \\
\hline Sibling conflict & 0.69 & 0.33 & .41 & 0.08 & 0.12 & .13 & 0.16 & 0.15 & .21 & 0.01 & 0.02 & .02 & 0.32 & 0.12 & $.45^{*}$ \\
\hline Sibling power & -0.05 & 0.38 & -.02 & 0.04 & 0.15 & .05 & -0.08 & 0.18 & -.08 & -0.01 & 0.03 & -.08 & 0.17 & 0.15 & .18 \\
\hline Maternal/Paternal partiality & 0.48 & 1.04 & .08 & 0.43 & 0.42 & .18 & 0.24 & 0.51 & .09 & -0.15 & 0.07 & $-.30^{*}$ & 0.09 & 0.41 & .03 \\
\hline General maladaptation of older sibling & 0.08 & 0.21 & .08 & & & & & & & & & & & & \\
\hline Social maladaptation of older sibling & & & & 0.07 & 0.19 & .07 & & & & & & & & & \\
\hline Personal maladaptation of older sibling & & & & & & & -0.03 & 0.25 & -.03 & & & & & & \\
\hline Family dissatisfaction of older sibling & & & & & & & & & & 0.26 & 0.15 & .30 & & & \\
\hline School maladaptation of older sibling & & & & & & & & & & & & & 0.38 & 0.17 & $.37^{*}$ \\
\hline
\end{tabular}

${ }^{\mathrm{a}} R^{2}=.71, p>.05 .{ }^{\mathrm{b}} R^{2}=.58 . p>.05 .{ }^{\mathrm{c}} R^{2}=.69 . p>.05 .{ }^{\mathrm{d}} R^{2}=.71 . p>.05 .{ }^{\mathrm{e}} R^{2}=.68 . p=.034$.

${ }^{*} p<.05 .{ }^{\dagger} .10>p>.05$. 


\section{Discussion}

This study drew on two perspectives: a perspective based on the findings that confirm that sibling relations have an important impact on children's psychological well-being (McHale et al., 2012); the other perspective focused on the theory of social learning, which emphasizes modeling as a key process whereby older siblings influence the behavior and adaptation of their younger siblings (Bandura, 2001; Whiteman et al., 2010). Therefore, the objective of this study was to analyze the variables that explain younger siblings' adaptive behavior, differentiating the contributions of variables of the sibling relationship and variables of the older siblings, as well as taking into account other family and individual variables.

On the one hand, the correlational analyses of this study reveal the protector role of the trait of agreeableness against the younger siblings' level of maladaptation, confirming that certain temperament traits like this are associated with children's higher levels of social adaptation (Asendorpf \& Van Aken, 2003). Following with the possible protective factors against child maladjustment, the negative correlation between sibling warmth and various levels of maladaptation in this study supports the positive and close relations between siblings as a facilitator of children's adaptation, as already indicated in other studies (Conger \& Kramer, 2010; Kennedy \& Kramer, 2008). This result supports continuing to analyze the processes described in the buffering hypothesis that posits that positive sibling relationships are associated with children's lower levels of internalizing symptoms (Pike, Coldwell, \& Dunn, 2005; Richmond, Stocker, \& Rienks, 2005). Finally, the associations between different aspects of interparental conflict and everyday stress and the level of child maladjustment are not surprising, given the extensive literature that identifies both variables as clearly harmful for children and adolescents' health and adaptation (Crnic \& Greenberg, 1990; Crnic et al., 2005; Crouter et al., 2001).

Notwithstanding the foregoing, the model that analyzed the younger siblings' maladaptation to school was significant, showing positive associations both with the older siblings' level of school maladaptation and with sibling conflict. According to these results, there is also a significant and positive association between the school maladaptation of both siblings. Therefore, these results could be interpreted from the classical theory of social learning (Bandura, 2001) of siblings' mutual influence, because the association of both siblings' level of school maladaptation can be considered as an evidence of the correlation between siblings' academic outcomes. In line with this, future studies with causal design could study the role of older siblings as models in the academic area for their younger siblings, supporting the scarce literature on the subject (Bouchey et al., 2010). The sibling relations are an important scenario of socialization due to the great amount of time they spend together through the whole lifespan and because siblings are usual the first same-age individual that a person interact with. From this perspective, the association between sibling conflict and the younger siblings' school maladjustment can be considered evidence of the association of sibling relations, in this case negative, on the children's health and well-being (Conger \& Kramer, 2010; McHale et al., 2012).

In addition, this model emphasizes other variables that explain younger siblings' school adaptation: sex, in particular being female, protects against school maladjustment (Kaur \& Chawla, 2016). Some authors have explained results like this because girls have better social and emotional adjustment, which is associated with better academic adjustment (Kasinath, 2003). Moreover, in this study family stress appears to be a factor that favors younger siblings' school maladjustment (Crnic \& Greenberg, 1990).

Finally, we note several limitations of this study. The sample size is not negligible, given that we used sibling dyads of children and adolescents. Therefore, the sample size does not allow obtaining definitive conclusions based just on these results and this research line needs to enlarge the sample to attain more demonstrative results. Increasing the sample size of future studies would allow the separate analysis of sibling relations and socialization processes in childhood and adolescence, as well as improve the statistical power of the analyses. Moreover, the age range of the sample is too broad (from 7 to 18 years-old participants) and that could affect the results because there are differences in the sibling relationships, individual adaptation and family processes depending on the developmental stage of the sons and daughters. Also, some of the subscales of the instruments do not reach adequate validity values, which hinders the interpretation of the results of this study. An additional limitation is that this study used an unpublished Spanish translated assessment of sibling quality. Future studies would benefit from longitudinal designs that would allow making causal inferences to explain younger siblings' adaptation. Finally, the results of this study are limited to Basque families due to the places where the sample was obtained, so there is a need to replicate studies in this area with 
different samples, especially with participants from non-Western cultures to analyze the impact of cultural differences in the adaptation of younger siblings. Therefore, taking into account all the mentioned limitations, this research line would need future studies with a longitudinal methodology compared to this pilot study, in order to produce causal conclusions.

Funding: This research was funded by the Basque Government, Predoctoral Grant BFI-2010-78.

Acknowledgments: The authors have no additional (i.e., non-financial) support to report.

Competing Interests: The authors have declared that no competing interests exist.

\section{References}

Asendorpf, J. B., \& Van Aken, M. A. (2003). Personality-relationship transaction in adolescence: Core versus surface personality characteristics. Journal of Personality, 71(4), 629-666. https://doi.org/10.1111/1467-6494.7104005

Bandura, A. (1973). Aggression: A social learning analysis. Oxford, United Kingdom: Prentice Hall.

Bandura, A. (2001). Social cognitive theory: An agentic perspective. Annual Review of Psychology, 52, 1-26.

https://doi.org/10.1146/annurev.psych.52.1.1

Barbaranelli, C., Caprara, G. V., \& Rabasca, A. (2006). BFQ-NA. Cuestionario "big five" de personalidad para niños y adolescentes. Manual [BFQ-NA: "Big Five" personality questionnaire for children and adolescentes. Manual]. Madrid, Spain: TEA Ediciones.

Barbaranelli, C., Caprara, G. V., Rabasca, A., \& Pastorelli, C. (2003). A questionnaire for measuring the Big Five in late childhood. Personality and Individual Differences, 34(4), 645-664. https://doi.org/10.1016/S0191-8869(02)00051-X

Bouchey, H. A., Shoulberg, E. K., Jodl, K. M., \& Eccles, J. S. (2010). Longitudinal links between older sibling features and younger siblings' academic adjustment during early adolescence. fournal of Educational Psychology, 102(1), 197-211.

https://doi.org/10.1037/a0017487

Branje, S. J. T., Van Lieshout, C. F. M., Van Aken, M. A. G., \& Haselager, G. J. T. (2004). Perceived support in sibling relationships and adolescent adjustment. Journal of Child Psychology and Psychiatry, and Allied Disciplines, 45(8), 1385-1396.

https://doi.org/10.1111/j.1469-7610.2004.00332.x

Brody, G. H. (1998). Sibling relationship quality: Its causes and consequences. Annual Review of Psychology, 49, 1-24. https://doi.org/10.1146/annurev.psych.49.1.1

Brown, J. R., \& Dunn, J. (1996). Continuities in emotion understanding from three to six years. Child Development, 67(3), 789-802. https://doi.org/10.2307/1131861

Buchanan, C., \& Heiges, K. (2001). When conflict continues after the marriage ends: Effects of postdivorce conflict on children. In J. Grych \& F. Fincham (Eds.), Interparental conflict and child development: Theory, research and applications (pp. 337-362). Cambridge, United Kingdom: Cambridge University Press. https://doi.org/10.1017/СBO9780511527838.015

Buhrmester, D. (1992). The developmental courses of sibling and peer relationships. In F. Boer, \& J. Dunn (Eds.), Children's sibling relationships: Developmental and clinical issues (pp. 19-40). Hillsdale, NJ, USA: Erlbaum.

Buist, K. L., Paalman, C. H., Branje, S. J. T., Deković, M., Reitz, E., Verhoeven, M., . . Hale, W. W., III. (2014). Longitudinal effects of sibling relationship quality on adolescent problem behavior: A cross-ethnic comparison. Cultural Diversity \& Ethnic Minority Psychology, 20(2), 266-275. https://doi.org/10.1037/a0033675

Canale, N., Vieno, A., Griffiths, M. D., Siciliano, V., Cutilli, A., \& Molinaro, S. (2017). "I am becoming more and more like my eldest brother!": The relationship between older siblings, adolescent gambling severity, and the attenuating role of parents in a largescale nationally representative survey study. Fournal of Gambling Studies, 33(2), 425-435. https://doi.org/10.1007/s10899-016-9643-5

Conger, K. J., \& Kramer, L. (2010). Introduction to the special section: Perspectives on sibling relationships: Advancing child development research. Child Development Perspectives, 4(2), 69-71. https://doi.org/10.1111/j.1750-8606.2010.00120.x

Crnic, K. A., Gaze, C., \& Hoffman, C. (2005). Cumulative parenting stress across the preschool period: Relations to maternal parenting and child behaviour at age 5. Infant and Child Development, 14(2), 117-132. https://doi.org/10.1002/icd.384 
Crnic, K. A., \& Greenberg, M. T. (1990). Minor parenting stresses with young children. Child Development, 61(5), $1628-1637$. https://doi.org/10.2307/1130770

Crouter, A. C., Bumpus, M. F., Head, M. R., \& McHale, S. M. (2001). Implications of overwork and overload for the quality of men's family relationships. Fournal of Marriage and the Family, 63(2), 404-416. https://doi.org/10.1111/j.1741-3737.2001.00404.x

Crouter, A. C., Whiteman, S. D., McHale, S. M., \& Osgood, D. W. (2007). Development of gender attitude traditionality across middle childhood and adolescence. Child Development, 78, 911-926. https://doi.org/10.1111/j.1467-8624.2007.01040.x

Cummings, E. M., Davies, P. T., \& Simpson, K. S. (1994). Marital conflict, gender, and children's appraisals and coping efficacy as mediators of child adjustment. fournal of Family Psychology, 8(2), 141-149. https://doi.org/10.1037/0893-3200.8.2.141

D’Amico, E. J., \& Fromme, K. (1997). Health risk behaviors of adolescent and young adult siblings. Health Psychology, 16(5), 426-432. https://doi.org/10.1037/0278-6133.16.5.426

Davies, P. T., Martin, M. J., \& Cicchetti, D. (2012). Delineating the sequelae of destructive and constructive interparental conflict for children within an evolutionary framework. Developmental Psychology, 48(4), 939-955. https://doi.org/10.1037/a0025899

Dillman Taylor, D., Purswell, K., Lindo, N., Jayne, K., \& Fernando, D. (2011). The impact of child parent relationship therapy on child behavior and parent-child relationships: An examination of parental divorce. International fournal of Play Therapy, 20(3), $124-137$. https://doi.org/10.1037/a0024469

Dunn, J., Brown, J., Slomkowski, C., Tesla, C., \& Youngblade, L. M. (1991). Young children's understanding of other people’s feelings and beliefs: Individual differences and their antecedents. Child Development, 62(6), 1352-1366. https://doi.org/10.2307/1130811

Dunn, J., \& Munn, P. (1986). Siblings and the development of prosocial behaviour. International fournal of Behavioral Development, 9(3), 265-284. https://doi.org/10.1177/016502548600900301

Dunn, J., Slomkowski, C., \& Beardsall, L. (1994). Sibling relationships from the preschool period to through middle childhood and early adolescence. Developmental Psychology, 30(3), 315-324. https://doi.org/10.1037/0012-1649.30.3.315

East, P. L., \& Jacobson, L. A. (2001). The younger siblings of teenage mothers: A follow-up of their pregnancy risk. Developmental Psychology, 37(2), 254-264. https://doi.org/10.1037/0012-1649.37.2.254

Edwards, R., Mauthner, M., \& Hadfield, L. (2005). Children's sibling relationships and gendered practices, talk, activity and dealing with change. Gender and Education, 17(5), 499-513. https://doi.org/10.1080/09540250500192678

Fagan, A. A., \& Najman, J. M. (2005). The relative contributions of parental and sibling substance use to adolescent tobacco, alcohol, and other drug use. fournal of Drug Issues, 35(4), 869-883. https://doi.org/10.1177/002204260503500410

Faul, F., Erdfelder, E., Lang, A. G., \& Buchner, A. (2007). G*Power 3: A flexible statistical power analysis program for the social, behavioral, and biomedical sciences. Behavior Research Methods, 39(2), 175-191. https://doi.org/10.3758/BF03193146

Formoso, D., Gonzales, N. A., \& Aiken, L. S. (2000). Family conflict and children's internalizing and externalizing behavior: Protective factors. American fournal of Community Psychology, 28(2), 175-199. https://doi.org/10.1023/A:1005135217449

Furman, W., \& Buhrmester, D. (1985). Children's perceptions of the qualities of sibling relationships. Child Development, 56(2), 448-461. https://doi.org/10.2307/1129733

Hernández, P. H. (1983). TAMAI: Test autoevaluativo multifactorial de adaptación infantil: Manual [TAMAI: Multifactorial SelfAssessed Test of Child Adjustment: Manual]. Madrid, Spain: TEA Ediciones.

Hornor, G. (2005). Domestic violence and children. Journal of Pediatric Health Care, 19(4), 206-212. https://doi.org/10.1016/j.pedhc.2005.02.002

Jensen, A. C., \& McHale, S. M. (2015). What makes siblings different? The development of sibling differences in academic achievement and interests. Fournal of Family Psychology, 29(3), 469-478. https://doi.org/10.1037/fam0000090

Jensen, A. C., Pond, A. M., \& Padilla-Walker, L. (2015). Why can't I be more like my brother? The role and correlates of sibling social comparison orientation. Journal of Youth and Adolescence, 44(11), 2067-2078. https://doi.org/10.1007/s10964-015-0327-8

Kasinath. (2003). Home environment, mental health and academic achievement among high school students. fournal of Education and Practice, 1(1), 1-7.

Kaur, H., \& Chawla, A. (2016). School adjustment: A comparative study of gender differences among adolescents. Indian fournal of Positive Psychology, 7(4), 466-468. https://doi.org/10.15614/ijpp\%2F2016\%2Fv7i4\%2F133897

Kennedy, D. E., \& Kramer, L. (2008). Improving emotion regulation and sibling relationship quality: The more fun with sisters and brothers program. Family Relations, 57(5), 567-578. https://doi.org/10.1111/j.1741-3729.2008.00523.x

Kramer, L., \& Bank, L. (2005). Sibling relationship contributions to individual and family well-being: Introduction to the special issue. Journal of Family Psychology, 19(4), 483-485. https://doi.org/10.1037/0893-3200.19.4.483 
Kramer, L., \& Conger, K. J. (2009). What we learn from our sisters and brothers: For better or for worse. New Directions for Child and Adolescent Development, 2009(126), 1-12. https://doi.org/10.1002/cd.253

Kumar, A., Thomas, S., \& Deb, S. (2015). The dynamics of sibling relations in adolescent development: Understanding the protective and risk factors. Indian fournal of Positive Psychology, 6(4), 439-443.

Lee, M., Vernon-Feagans, L., Vazquez, A., \& Kolak, A. (2003). The influence of family environment and child temperament on work/ family role strain for mothers and fathers. Infant and Child Development: An International fournal of Research and Practice, 12(5), 421-439. https://doi.org/10.1002/icd.323

MacKinnon-Lewis, C., Starnes, R., Volling, B., \& Johnson, S. (1997). Perceptions of parenting as predictors of boys' sibling and peer relations. Developmental Psychology, 33(6), 1024-1031. https://doi.org/10.1037/0012-1649.33.6.1024

Martínez-Pampliega, A., Aguado, V., Corral, S., Cormenzana, S., Merino, L., \& Iriarte, L. (2015). Protecting children after a divorce: Efficacy of egokitzen-an intervention program for parents on children's adjustment. fournal of Child and Family Studies, 24, 3782-3792. https://doi.org/10.1007/s10826-015-0186-7

McDonald, R., \& Grych, J. H. (2006). Young children's appraisals of interparental conflict: Measurement and links with adjustment problems. Fournal of Family Psychology, 20(1), 88-99. https://doi.org/10.1037/0893-3200.20.1.88

McElwain, N. L., \& Volling, B. L. (2005). Preschool children's interactions with friends and older siblings: Relationship specificity and joint contributions to problem behavior. Journal of Family Psychology, 19(4), 486-496. https://doi.org/10.1037/0893-3200.19.4.486

McHale, S. M., Bissell, J., \& Kim, J. E. (2009). Sibling relationship, family, and genetic factors in sibling similarity in sexual risk. Journal of Family Psychology, 23(4), 562-572. https://doi.org/10.1037/a0014982

McHale, S. M., Updegraff, K. A., Helms-Erikson, H., \& Crouter, A. C. (2001). Sibling influences on gender development in middle childhood and early adolescence: A longitudinal study. Developmental Psychology, 37(1), 115-125.

https://doi.org/10.1037/0012-1649.37.1.115

McHale, S. M., Updegraff, K. A., \& Whiteman, S. D. (2012). Sibling relationships and influences in childhood and adolescence. fournal of Marriage and the Family, 74(5), 913-930. https://doi.org/10.1111/j.1741-3737.2012.01011.x

Menesini, E., Camodeca, M., \& Nocentini, A. (2010). Bullying among siblings: The role of personality and relational variables. British fournal of Developmental Psychology, 28(4), 921-939. https://doi.org/10.1348/026151009X479402

Morgado Camacho, B., \& González Rodríguez, M. D. M. (2001). Divorcio y ajuste psicológico infantil. Primeras respuestas a algunas preguntas repetidas [Divorce and child psychological adjustment: First answers to some frequent questions]. Apuntes de Psicología, 30(1-3), 351-360.

Nixon, C. L., \& Cummings, E. M. (1999). Sibling disability and children's reactivity to conflicts involving family. Fournal of Family Psychology, 13(2), 274-285. https://doi.org/10.1037/0893-3200.13.2.274

Ortiz, M. Á. C., Tello, F. P. H., \& del Barrio Gándara, V. (2005). Dimensionalidad del cuestionario de los cinco grandes (BFQ-N) en población infantil española [Dimensionality of the Big Five (BFQ-N) Questionnaire in Spanish child population]. Psicothema, 17(2), 286-291.

Patterson, G. R. (1984). Siblings: Fellow travelers in coercive family processes. In R. J. Blanchard (Ed.), Advances in the study of aggression (pp. 174-213). New York, NY, USA: Academic Press.

Pike, A., Coldwell, J., \& Dunn, J. F. (2005). Sibling relationships in early/middle childhood: Links with individual adjustment. fournal of Family Psychology, 19(4), 523-532. https://doi.org/10.1037/0893-3200.19.4.523

Pike, A., \& Oliver, B. R. (2017). Child behavior and sibling relationship quality: A cross-lagged analysis. fournal of Family Psychology, 31(2), 250-255. https://doi.org/10.1037/fam0000248

Ponappa, S., Bartle-Haring, S., Holowacz, E., \& Ferriby, M. (2017). The Family system and depressive symptoms during the college years: Triangulation, parental differential treatment, and sibling warmth as predictors. Fournal of Marital and Family Therapy, 43(1), 145-158. https://doi.org/10.1111/jmft.12175

Richmond, M. K., Stocker, C. M., \& Rienks, S. L. (2005). Longitudinal associations between sibling relationship quality, parental differential treatment, and children's adjustment. Journal of Family Psychology, 19(4), 550-559. https://doi.org/10.1037/0893-3200.19.4.550

Rodgers, J. L., Rowe, D. C., \& Harris, D. F. (1992). Sibling differences in adolescent sexual behavior: Inferring process models from family composition patterns. Fournal of Marriage and the Family, 54(1), 142-152. https://doi.org/10.2307/353282

Slomkowski, C., Rende, R., Conger, K. J., Simons, R. L., \& Conger, R. D. (2001). Sisters, brothers, and delinquency: Evaluating social influence during early and middle adolescence. Child Development, 72(1), 271-283. https://doi.org/10.1111/1467-8624.00278 
Slomkowski, C., Rende, R., Novak, S., Lloyd-Richardson, E., \& Niaura, R. (2005). Sibling effects on smoking in adolescence: Evidence for social influence from a genetically informative design. Addiction, 100(4), 430-438.

https://doi.org/10.1111/j.1360-0443.2004.00965.x

Stormshak, E. A., Bellanti, C., Bierman, K. L., Coie, J. D., Dodge, K. A., \& Greenberg, M. T. (1996). The quality of sibling relationships and the development of social competence and behavioral control in aggressive children. Developmental Psychology, 32(1), 79-89. https://doi.org/10.1037/0012-1649.32.1.79

Trianes Torres, M. V., Mena, M. J. B., Baena, F. J. F., Espejo, M. E., Montero, E. F. M., \& Sánchez, Á. M. M. (2009). Evaluación del estrés infantil: Inventario infantil de estresores cotidianos (IIEC) [Evaluation of child stress: Child Inventory of Everyday Stressors (IIEC)]. Psicothema, 21(4), 598-603.

Trim, R. S., Leuthe, E., \& Chassin, L. (2006). Sibling influence on alcohol use in a young adult, high-risk sample. Fournal of Studies on Alcohol, 67(3), 391-398. https://doi.org/10.15288/jsa.2006.67.391

Tsamparli, A., \& Frrokaj, E. (2016). Quality of sibling relationship and substance misuse: A comparative study. The European fournal of Counselling Psychology, 4(1), 123-147. https://doi.org/10.5964/ejcop.v4i1.78

Tucker, C. J., Updegraff, K. A., McHale, S. M., \& Crouter, A. C. (1999). Older siblings as socializers of younger siblings' empathy. The Journal of Early Adolescence, 19(2), 176-198. https://doi.org/10.1177/0272431699019002003

Updegraff, K. A., McHale, S. M., \& Crouter, A. C. (2002). Adolescents' sibling relationship and friendship experiences: Developmental patterns and relationship linkages. Social Development, 11(2), 182-204. https://doi.org/10.1111/1467-9507.00194

Updegraff, K. A., McHale, S. M., Whiteman, S. D., Thayer, S. M., \& Delgado, M. Y. (2005). Adolescent sibling relationship in Mexican American families: Exploring the role of familism. Fournal of Family Psychology, 19(4), 512-522.

https://doi.org/10.1037/0893-3200.19.4.512

Wheeler, L. A., Killoren, S. E., Whiteman, S. D., Updegraff, K. A., Mchale, S. M., \& Umaña-Taylor, A. J. (2016). Romantic relationship experiences from late adolescence to young adulthood: The role of older siblings in Mexican-origin families. Fournal of Youth and Adolescence, 45(5), 900-915. https://doi.org/10.1007/s10964-015-0392-z

Whiteman, S. D., Becerra Bernard, J., \& McHale, S. M. (2010). The nature and correlates of sibling influence in two-parent African American families. Journal of Marriage and the Family, 72(2), 267-281. https://doi.org/10.1111/j.1741-3737.2010.00698.x

Whiteman, S. D., McHale, S. M., \& Crouter, A. C. (2007). Explaining sibling similarities: Perceptions of sibling influences. Journal of Youth and Adolescence, 36, 963-972. https://doi.org/10.1007/s10964-006-9135-5

Zukow-Goldring, P. (2002). Sibling caregiving. In M. H. Bornstein (Ed.), Handbook of parenting: Being and becoming a parent (pp. 253-286). Mahwah, NJ, USA: Erlbaum.

\section{About the Authors}

Laura Merino is $\mathrm{PhD}$ and lecturer in the Department of Social and Developmental Psychology at Universidad de Deusto in Bilbao (Spain). Research topics about siblings, divorce, family functioning and parent-child relationships.

Ana Martínez-Pampliega is Professor of Psychology in the Department of Social and Developmental Psychology, Universiy of Deusto in Bilbao (Spain). Director of the MA in Systemic-Relational Psychotherapy and the Deusto FamilyPsych research group.

David Herrero-Fernández is $\mathrm{PhD}$ and lecturer in the Department of Psychology at Universidad Europea del Atlántico in Santander (Spain). Research topics about driving anger, risk perception, risky behaviour, psychophysiological assessment, and road safety. 